University of Nebraska - Lincoln

DigitalCommons@University of Nebraska - Lincoln

Faculty Publications: Agricultural Leadership, Education \& Communication Department
Agricultural Leadership, Education \& Communication Department

September 1992

\title{
Tools for Managing Design and Development of a Twenty-first Century Technology Base
}

James W. King

University of Nebraska-Lincoln, jking1@unl.edu

Richard Cornell

University of Central Florida

Follow this and additional works at: https://digitalcommons.unl.edu/aglecfacpub

Part of the Other Public Affairs, Public Policy and Public Administration Commons

King, James W. and Cornell, Richard, "Tools for Managing Design and Development of a Twenty-first Century Technology Base" (1992). Faculty Publications: Agricultural Leadership, Education \& Communication Department. 46.

https://digitalcommons.unl.edu/aglecfacpub/46

This Article is brought to you for free and open access by the Agricultural Leadership, Education \& Communication Department at DigitalCommons@University of Nebraska - Lincoln. It has been accepted for inclusion in Faculty Publications: Agricultural Leadership, Education \& Communication Department by an authorized administrator of DigitalCommons@University of Nebraska - Lincoln. 


\title{
Tools for Managing Design and Development of a Twenty-first Century Technology Base
}

\author{
James W. King and Richard A. Cornell
}

\begin{abstract}
This article describes what is involved in future projections for technology-based learning, and highlights the importance of the management of educational technologies. It looks at various organizational models, as well as models of personal vision.
\end{abstract}

\section{Introduction}

In today's ever-changing organization and institutional environment, managing educational technology and positioning it for the twenty-first century is 'difficult.' With restructuring, tight budgets, and personnel issues, amidst the demands of new educational hardware and learning and performance technologies, managers have no difficulties in finding problems and issues of concern.

Examining educational literature and technology, we see four major trends (Cornell, 1989; 1990). These include life-long learning; changing space design and allocation requirements for technology-based learning facilities; more information being present, as well as vast changes in the means of formatting that information; lastly, attitude change in all the participants in the educational sector. To realize each of these requires reconceptualizing the many aspects of the instructional setting; nevertheless, managers do have a series of planning tools to help them to design, develop and get ready for these futures. And to implement a technology-based future in both formal and non-formal education, planning, thinking about and 'visioning' the future will be imperative.

While our general framework and thrust are towards managing technology, the tools and techniques discussed focus on the 'high touch', people-oriented interventions. We call these 'peopleware'. The late Charles Lindbergh upheld a passionate belief in the wisdom of creating a balance between our various technologies and humankind (Lindbergh Funds, 1992). We also believe in the balance between individuals and their tools, and will begin with one way in which educators can blend the technology and the people - through management.

\section{Management}

Hersey and Blanchard (1982) define management as the 'working with and through individuals and groups to accomplish organizational goals' (p.3). While managing educational technology to achieve goals and objectives, we have to work with and through people to achieve certain desired ends. This definition obviously has a very people-oriented distinctiveness. To manage individuals in both the current context and in the 'chaos' (Peters, 1987) of tomorrow's organizational atmosphere, it will be extremely important -in fact necessary -to think about the future.

The literature is packed with reports on technology and management (King, 1984; Leonard-Barton and DeSchamps, 1988; Nomikos, 1989), success and failure of educational technologies (Gayeski, 1989; Stockdill and Morehouse, 1991), and organizational development (Karz and Gartner, 1988; Poupart and Hobbs, 1989). To us, a 'futures'-oriented linkage is needed between these seemingly diverse elements. By definition, the future is unknown. Nevertheless, we believe that it can be designed by organizational and personal goal setting and visioning. Examples show us that we do not have to be slaves to trends, histories and traditions. In particular, there are visioning tools to help managers of technology.

\section{Organizational vision}

Organizational vision is critical for today's managers of tomorrow's educational technologies. We define organizational visions as the ways in which organizations and the people in them see the future and their roles, and there are several tools and models which we have found to be helpful in creating and developing organizational vision.

\section{Wheeler Organizational Model (Wheeler, 1990)}

Organizations often react to change in traditional ways. They focus and concentrate their internal energies on resources and structure, and they miss oppor- 
tunities to acknowledge, use and develop two other existing organizational attributes — vision and power. The Wheeler model, presented in Figure 1, combines these four organizational characteristics to oversee change. One way to direct group change involves developing a balance between four major elements: vision, power, structure and resources.

Vision is a combination of both a direction for a desired future state of an organization, i.e. goals and strategies and its image. Characteristics of organizational visions include (1) shared and supported statements, (2) comprehensive and detailed plans, (3) positive and inspiring descriptions and (4) results in a vision community (Barker, 1990). Questions to guide the design and development of an organizational vision are summarized in Table 1.

In an organizational setting, power relates to the capacity to achieve goals and objectives - getting things done. Power in organizations is derived from two channels: first, power from explicit, authority frameworks such as organizational hierarchies and job descriptions and second, casual power sources such as knowledge, persuasion and charisma.

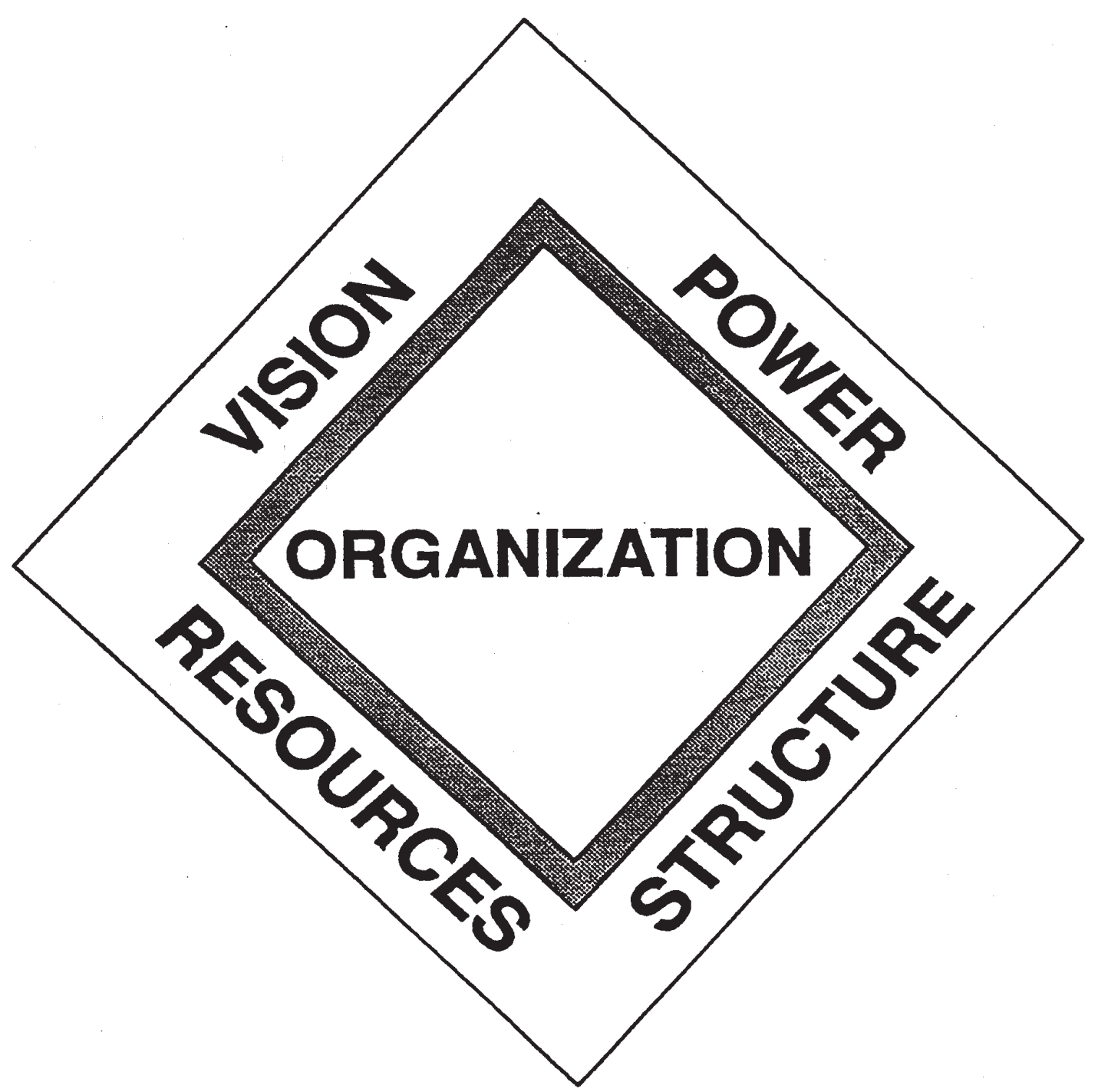

Figure 1. Four organizational attributes to effectively oversee change (based on Wheeler, 1990) 


\section{Vision}

1.1. What is the present vision? Is it a duplication of the past? Is it a shifting of past priorities? Does it include a new image of the mission?

1.2. If individual units and administrators have their visions of the future, how do these fit into the comprehensive, overall vision for the organization?

1.3. What is the future vision? Is it a continuation of the present? Is it something embodied in a specific person or group of people? Is it a response to outside forces?

1.4. What will be essential to have in the vision to enable people to understand and buy into it? Is there anything to add to the vision characteristics noted in the text?

1.5. Who needs to be involved in the visioning process? Will it be a designated, legitimized group? Should it be the total administrative group? Should it be a particular committee? Could acknowledged 'futurists' be included?

1.6. Once a new vision is developed, how can those in the organization start to accept or buy into the vision? How can the vision be kept visible to everyone?

\section{Power}

2.1. How can people be empowered to meet their responsibilities? Should there be clearer messages about responsibilities and the authority to accomplish them? Should more attention be paid to the casual sources as well as to the fixed, formal system?

2.2. What is the relationship of empowerment to the structure of the organization? Do job descriptions and rules and regulations help to empower? Are there any aspects of the current structure that are particularly problematic to a technology-based operation?

2.3. What is being done to increase power through development of intellectual resources? What else should the organization be doing?

2.4. What are the incentives to give up positions and resources for the greater good of the organization?

\section{Structure}

3.1. Is there sufficient structure in the organization to meet the need for stability in a time of rapid change? Is there too much structure inhibiting organizational transformation for new educational arrangements and linkages?

3.2. If job descriptions and assignments are central to getting the work of the organization accomplished, are there adjustments that need to be made? Could more specificity assist and help? Should there be less specificity? Do these job descriptions and assignments inhibit creativity and flexibility in a technology-driven system?

3.3. Are there areas of policies and procedures which inhibit moving in the future? Are there personnel issues which curb getting visions implemented and accomplished? Are there other structural issues, such as relationships with various units?

3.4. Should more of the structure be temporary in nature - that is, only in place long enough to enable the work to be accomplished and then dissolved?

\section{Resources}

4.1. Will there be more resources in the future? Will there be more, but only in designated areas, or only through outside funds or outside linkages? Will there be more for certain types of support activities or research? Will there be more resources in other areas?

4.2. What is the likelihood of fewer resources or, at best, 'steady state' resources in the future? What will happen to the number of staff positions? What will happen with the number of support positions? What about acquiring new equipment and supplies? What will happen to maintenance functions?

4.3. If there are no, or few, new resources how can the organization make adjustments in the future? How can we retrain our present personnel? How can we discontinue programs and activities? Can we narrow our focus? Can we expect more from others outside the organization?

Table 1. Organizational questions

Each organization furnishes some structure or framework in which individuals can perform their work. For a manager, basic questions concern the quantity and detail of structure necessary to realize organizational goals, and the types of structuring which are helpful to achieve those goals. Should managers first decide organizational functions and then organize the system to accomplish those functions? Or does some structuring suppress continuous argument on every new issue which develops? Many technology-based organizations are today becoming more 'decentralized,' which means that they are providing manage- 
rial and organizational flexibility to move in new directions, not overloaded with structure.

Often managers and organizations feel that simply getting more resources will solve all problems. However, educational research shows that greater resources do not always lead to larger and greater endresults (Lunde et al., 1991). Organizational resources include both tangible and intangible items such as money, facilities and people.

Taken together, these four components-vision, power, structure and resources - can be used to review and mould organizational change and adaptation. Managers of educational technology systems can successfully apply and use the questions presented in Table 1 as part of their continuing processes of self- examination to develop future strategies.

Fifth Generation Management (Markley, 1989; Savage, 1988)

A new design for future-oriented organizations can replace the top-heavy structures of the past with collaborative and cooperative design. This model presents that view.

\begin{tabular}{|lll|}
\hline Generation & Management & Technology \\
\hline First & $\begin{array}{l}\text { Small/ } \\
\text { Entrepreneurial }\end{array}$ & Valve \\
& Hierarchical/ & Transistor \\
Fecond & Functional/ & \\
& Divisional & \\
Third & Matrix & Integrated \\
& & Circuits \\
Fourth & Networked & Networks \\
Fifth & Integrative & Electronic \\
& Organizations & $\begin{array}{l}\text { Highways/ } \\
\text { Telecottages }\end{array}$ \\
\hline
\end{tabular}

(Based on Markley, 1989)

Table 2. Managerial and Technology Generations
Fifth generation management is necessary for the movement in technology-dependent systems from simple to complex, from single systems to networks, from dependence to independence, and from centralized to decentralized. As shown in Table 2, generations move from minor to multifarious and parallel the motion of the technology.

This innovative management model expresses and embodies change, with knowledge centers, careers, education, informational memory, and data as an asset, as characteristics of this new style. It shifts from traditional hierarchical frameworks to what Markley (1989) calls 'nodal' arrangements. Figure 2 contrasts these two formats.

Fifth generation systems embody teams, anticipatory management, forecasting, and issues management. Many of the theoretical concepts and approaches of these systems as well as the practical methods, are highly desirable for educational technology systems.

A subset of fifth generation management is total quality management (TQM) (Journal of Management Science Policy Analysis, 1991), which offers techniques and philosophies for managing educational technology groups. TQM originated with, and grew from, the work of Deming (1986) and underpins much of today's highly acclaimed Japanese management style. TQM is currently being used by many US universities as they struggle towards redefining their goals and achieving new quality in programs.

The basic premise behind TQM is that most problems are management controllable; that is, the total organization of vision, power, resources and structure is a process or system that can be guided by proper management which involves all participants-workers, managers, and clients (students, other staff etc). TQM, like newer management ideas (Peters, 1987), sees management as leadership which changes from constraints on people to involving them in decisions affecting their work, with managers becoming more involved with staff and customers, working with, rather than always overseeing. Vision and power are

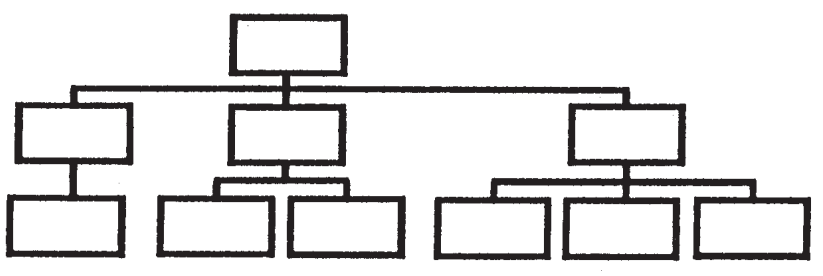

Traditional

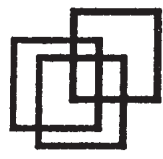

Nodal

Figure 2. Managerial frameworks (based on Markley, 1989) 
shared; resources are considered from the staff viewpoint; structures are flexible enough to deal with change yet adequately stable to provide an organizational framework.

TQM contends that access from staff to managers should be open and that regular forums should take place. Participation is a key premise - there should be no surprises 'out of the blue' for either management or staff.

In education, from the TQM viewpoint, students are generally seen as customers of the services we help to provide, but staff using educational technology and our support units are also our customers. Much of what we do is based on our customers' satisfaction with our work; TQM provides guidance in developing this process and in managing the day-today operations.

Emerging Technologies Model (Sandhorstet al., 1990)

New and better opportunities to manage technology may occur by restructuring or re-engineering existing resources through combining, eliminating, reallocating and sharing. Beaumont and Beaumont (1987a,b; 1988) present several interesting organizational models based on information flow and communications.

The restructuring model presented here was based on several assumptions: (1) that a blurring of jobs and functions is now occurring in computing and communication groups; (2) that educational technologies are evolving into dynamic systems; (3) that lines isolating 'traditional' disciplines are becoming less and less distinct. The elements of any successful technology system - computing, communication and human resources - are problematic. They do not fit into existing university patterns, with simple borders, within established and orthodox disciplines. Such novel constituents have clouded the traditional university structure. Coordinated solutions, first for people and then for technologies, are required in order to meet the educational technology challenges of the twenty-first century campus. A Center for Emerging Technologies in Computing, Communication and Human Resources (CET) was proposed (Sandhorst et al., 1990).

CET would bring together (1) computing and communication services - the integration of services; (2) professional and organizational development-focused on organizational and staff development activities; (3) technology assessment, computing and communication research and development, and facility planning - facilitation of the research, development and evaluation of new educational technologies; (4) 'think tank' applications - a provision for an organized and sanctioned framework for visioning. This model addresses perceived organizational barriers. CET would enhance multidisciplinary ties between computing, communication and human resources; Table 3 shows its goals.

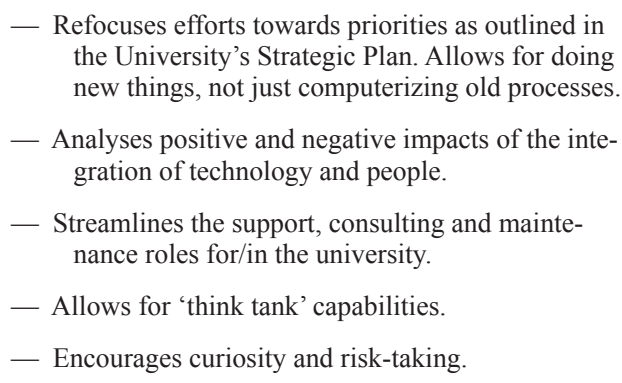
the University's Strategic Plan. Allows for doing new things, not just computerizing old processes.

- Analyses positive and negative impacts of the integration of technology and people.

- Streamlines the support, consulting and maintenance roles for/in the university.

- Allows for 'think tank' capabilities.

- Encourages curiosity and risk-taking.

(Source: Sandhorst et al, 1990)

Table 3. Goals for the Center for Emerging Technologies

CET's proposed structure came from the functions of the existing communication and computing programs, as well as innovative futuring activities. Figure 3 shows this re-engineered framework (see Hammer [1990] and Penrod and Dolence [1991] for explanations of re- engineering).

The think tank component is somewhat unusual. It is a future-oriented scanning group that encourages new ideas. Think tank activities focus on establishing environments for (1) planning, modeling and prototyping ideas; (2) analyzing positive and negative impact of suggested ideas; (3) creating a body of resource materials for sharing.

\section{Just-in-Time education (Hudspeth, 1992)}

Based on the concept of just-in-time (JIT) manufacturing (Duncan, 1988; Hernandez, 1989; Zipkin, 1991), Hudspeth is developing the concept of JIT education (JIT ed). JIT ed moves away from contemporary classroom-focused systems. It argues that all subject-matter instruction is available at whatever time it is needed, with level and materials appropriate for every individual, presented where convenient, and fitting technology to the learner. The basis for this thinking is that education in the next century will be technology-disposed and accommodating. Learners will be creating new demands on the system, so that managers will have to consider radically different processes of instructional delivery. Unique, individualized lessons, cooperative learning groups, and multi-technology choices from the learners and the designers will nurture learning styles in a variety of locations and cultures. 


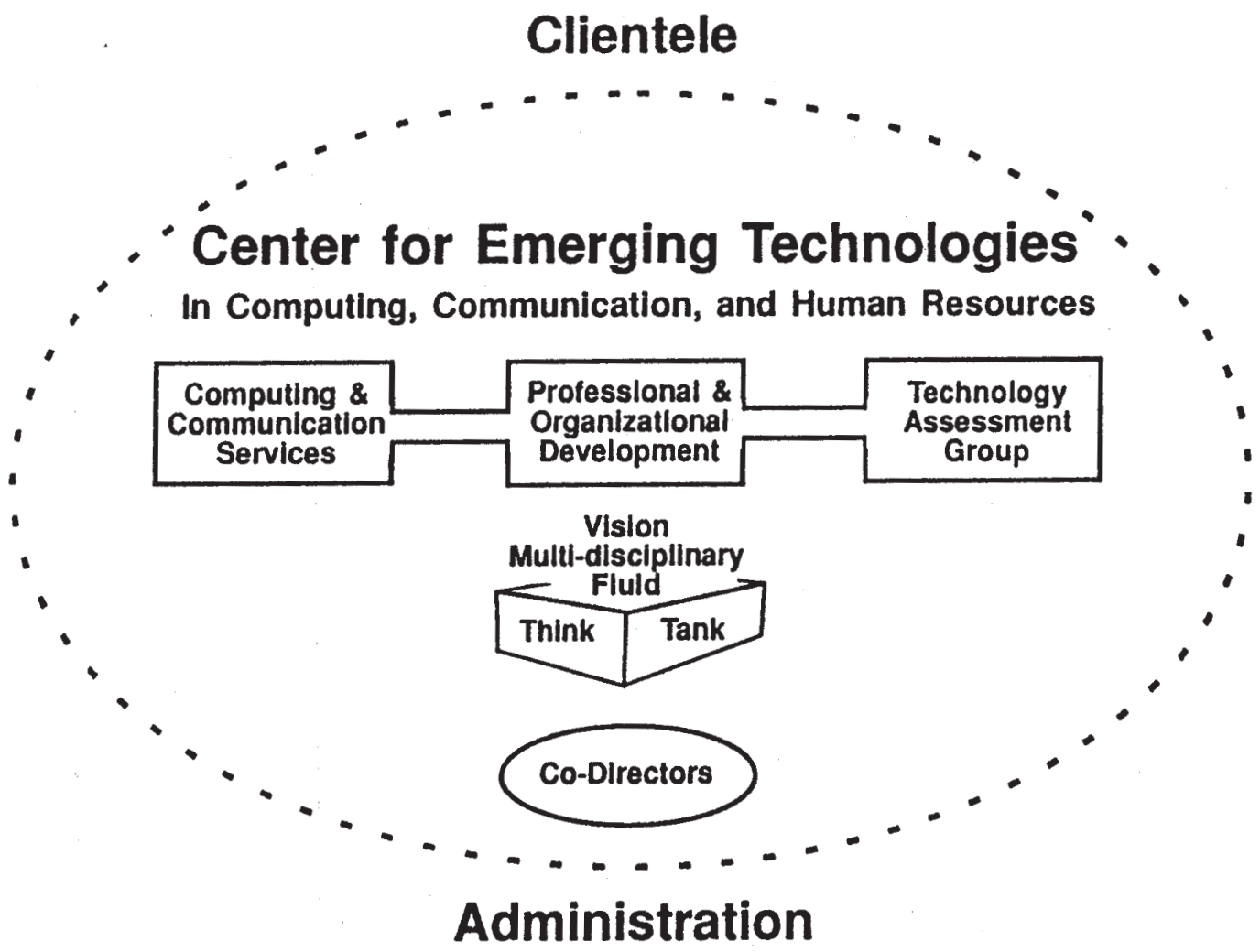

Figure 3. A framework for a proposed Center for Energy Technologies (Sandhorst et al., 1990)

For a system like this to prosper and succeed, total quality control is a key variable (Hudspeth, 1992). Thus, management tools like TQM (above) will be necessary.

\section{Personal vision}

Personal vision is a second type of vision which managers of educational technology systems must have. The development of organizational human resources for the twenty-first century is the underlying foundation for technological success. Tools for developing personal vision follow.

\section{Hellmer model (Hellmer, 1990)}

This process suggests 10 steps to create personal vision and we think it is a good model with which individuals may tie personal goals into organizational strategies. Ten steps to create a vision include the following.

1. Scanning the environment-determining key organizational and personal issues and trends of the past, present and future.

2. Identifying potential visions-listing 'wants' and wishes for the future, both in personal life and in business.

3. Inventorying resources — assessing current strengths, skills, talents, models, mentors and support systems.

4. Focusing on a vision-determining one issue or 'want' over which the individual has influence and choosing that 'want' for the vision.

5. Writing a future-specifying, as expressively as possible, what the future will be like.

6. Checking personal/organizational agreement-determining how well the personal vision itself is positioned within the organizational vision.

7. Choosing to act-deciding to implement the vision and taking responsibility.

8. Identifying what to unlearn and what to learnfiguring which old habits to drop or change and which new behaviors to learn.

9. Affirming the vision-writing one unambiguous declaration articulating the realized vision.

10. Cultivating the vision-developing personal ownership of the vision image. 
This process can be either collaborative or individual. Organizational mission statements can be woven within the developing individual visions. While this visioning technique does take time, we believe that it is time well spent since it makes the organization potent by having in place strong individuals who have identified future paths.

\section{Manager's Faculty Growth Model (Wilhite, Leini- nger and King, 1989)}

This model describes a process for staff management in organizations undergoing the stress of adapting to new technologies. Some of the factors for managing staff members in a media unit include the following.

1. Recruitment - an opportunity to bring new people and ideas into the unit as well as to re-evaluate the current status and determine possible new visions.

2. Communication-leader/staff communication offers an occasion for both to create shared visions.

3. Identification of goals - setting, distinguishing and aligning personal goals with unit goals helps to target a departmental course and is critical to longterm success, especially when many multi- disciplinary, technology-based and team- supported projects are involved.

4. Personnel support-staff assistance and support from managers, including release time, grant monies and equipment, are necessary to a vital and productive technology unit.

5. Evaluation-providing frequent and continuous feedback which assists staff can often help in setting goals and correct actions before larger problems occur.

6. Recognition-managers can use a number of ways in which to reward and recognize staff.

Combining these six activities with TQM and the Hellmer model, managers can create unit vision and assist individual development of vision. By enhancing faculty growth and development, strong, innovative future directions can be developed and encouraged for the unit.

\section{Resources}

Managers have a large range of resources for future work. Briefly, these include the following.

Journals-American Demographics, Whole Earth, Futures, Futures Research Quarterly, The Futurist, The Kappan, Technological Forecasting and Social Change, Technology Review.

Books-Discovering the Future (Barker, 1988), Future Edge (Barker, 1992), What Futurists Believe
(Coates and Jarratt, 1989).

Videos_-The Business of Paradigms (Barker, 1989), The Power of Vision (Barker, 1990).

Articles and reports-Amara 1991: ERIC Clearinghouse on Information Resources, US Congress Office of Technology Assessment (1989; 1990).

\section{Summary}

The interplay of organizational structure, personnel and technology management, as they fall under the umbrella of twenty-first century management strategies, will perhaps be the major factor in the success of educational technology, for, by and large, the technologies are driven by themselves, by corporate vendors, or by pressures from the community. Our own readings and studies, along with those of scholars worldwide (Cornell, 1992; Godet, 1990; Moenaert et al., 1992; Smith and Tranfield, 1986; Tranfield and Smith, 1988) lead us to make the following statement: we believe that the problems of educational technology are not the problems of the technologies themselves, but of their management.

Clearly, if any real leadership role is to be taken, it cannot be relegated to the overwhelming numbers of traditionalist-minded people who persist in adherence to maintenance of the status quo. It will have to be the individuals who are sufficiently interested in education for everyone at all levels, who can grasp the holistic future ahead and realize its potential impact. As leaders today and tomorrow, we will be called on to make a stand in support of the integral use of technology in education as each of us plans for the competencies required for a twenty-first century workforce.

We have described projections for the future-lifelong learning modes, the changing space design and allocation requirements for technology-based learning facilities of the future, the vast changes in the amount of information being presented as well as the means of formatting it and, finally, the changes in attitude which must come about on the part of both the learners and the technology managers alike.

Given each of these issues, we must turn our attention to an educational future which reflects the best of 'high' technology, the most caring of 'high touch', the peopleware concerns, and together, bring excitement,' involvement and innovation to the future. The tools and ideas presented here are a few ways of coping with change, designing desirable futures, and managing systems into the next century. 


\section{References}

Amara, R. (1991) Views on futures research methodology. Futures, 31, 645-649.

Barker, J. A. (1988) Discovering the Future: The Business of Paradigms. St. Paul, Minnesota: ILI Press.

Barker, J. A. (1989) The Business of Paradigms. Charthouse International Learning Corporation, Burnsville, Minnesota (videotape).

Barker, J. A. (1990) The Power of Vision. Charthouse International Learning Corporation, Burnsville, Minnesota (videotape).

Barker, J. A. (1992) Future Edge. New York: William Morrow.

Beaumont, J. R. and Beaumont, C. D. (1987a) Applied management information systems: thoughts on current practice and future potential. Futures, 19, 442-445.

Beaumont, J. R. and Beaumont, C. D. (1987b) Applied management information systems: business analysis. Futures, 19, 566-573.

Beaumont, J. R. and Beaumont, C. D. (1988) Applied management information systems: competitive advantage. Futures, 20, 69-77.

Coates, J. F. and Jarratt, J. (1989) What Futurists Believe. Bethesda, Maryland: World Future Society.

Cornell, R. A. (1989) Instructional Systems 2009: Building a 20-Year Technology Bridge. Paper presented at the Convegno Internazionale di Studi, Ferrara, Italy.

Cornell, R. A. (1990) Scenario 1999 and Beyond: In Search of an Intergalactic Media Center. Paper presented to the faculty of National Taiwan University, Taipei, Taiwan.

Cornell, R. A. (1992) Program management: its relationship to the project. In R. Kaufman, S. Thiagarajan, and P. MacGillis (eds. ) Practitioner's Handbook on Organization and Human Performance Improvement. San Diego, California: University Associates. In Press.

Deming, W. E. (1986) Out of the Crisis. Cambridge: MIT Center for Advanced Engineering Study.

Duncan, W. L. (1988) Just-In-Time in American Manufacturing. Dearborn, Michigan: Society of Manufacturing Engineers.

Gayeski, D. M. (1989) Why information technologies fail. Educational Technology, 29, 3, 9-17.
Godet, M. (1990) Integration of scenarios and strategic management. Futures, 30, 730-739.

Hammer, M. (1990) Re-engineering work: don't automate, obliterate. Harvard Business Review, 90, 4, 104-112.

Hellmer, J. W. (1990) Cultivating Personal Vision. Paper presented at the annual meeting of the $\mathrm{Na}-$ tional Society for Performance and Instruction, Toronto, Ontario.

Hernandez, A. (1989) Just-in-Time Manufacturing: A Practical Approach. Englewood Cliffs, New Jersey: Prentice-Hall.

Hersey, P. and Blanchard, K. (1982) Management of Organizational Behavior. Englewood Cliffs, New Jersey: Prentice-Hall.

Hudspeth, D. (1992) Just-in-Time Education. Educational Technology. In press.

Journal of Management Science Policy Analysis (1991) Special issues on Total Quality Management. 8, 3/4, 193-284.

Karz, J. and Gartner, W. B. (1988) Properties of emerging organizations. Academy of Management Review, 13, 429-441.

King, J. W. (1984) Management Issues in Development Support Communication. Paper presented at the Annual Meeting of the Association for Educational Communications and Technology, Anaheim, California.

Leonard-Barton, D. and DeSchamps, I. (1988) Managerial influence in the implementation of new technology. Management Science, 34, 12521265.

Lindbergh Funds, Inc, C. A. (1992) 1993 Lindbergh Grant Application. Minneapolis, Minnesota: Charles A. Lindbergh Funds, Inc.

Lunde, J. P., Wheeler, D. W., Hartung, T. E. and Wheeler, B. J. (1991) Second order change: impact of a college renewal program over time. Innovative Higher Education, 16,2, 125-138.

Markley, O. W. (1989) Explaining and implementing futures research: part II -more architectures for anticipating management. In H. F. Didsbury (ed) The Future: Opportunity Not Destiny. Bethesda, Maryland: World Future Society. pp. 200-213.

Moenaert, R. K., Deschoolmeester, D., De Meyer, A. and Souder, W. E. (1992) Information styles of marketing and R\&D personnel during technological product innovation projects. $R \& D$ Management, 22, 1, 21-39. 
Nomikos, G. E. (1989) Managing knowledge workers for productivity. National Productivity Review, 8, 165- 174.

Penrod, J. I. and Dolence M. G. (1991) Concepts for re-engineering higher education. CAUSE/EFFECT, 14,2, 10-17.

Peters, T. (1987) Thriving on Chaos: Handbook for a Management Revolution, New York: Knopf.

Poupart, R. and Hobbs, B. (1989) Changing the corporate culture to ensure success: a practical guide. National Productivity Review, 8, 223-238.

Sandhorst, B. C., Emal, J. G., King, J. W. and Wilhite, M. S. (1990) The Center for Emerging Technologies in Computing, Communication and Human Resources. In Managing Information Technology: Facing the Issues, Boulder, Colorado: CAUSE. 243-253.

Savage, C. M. (1988) Fifth Generation Management for Fifth Generation Technology. Dearborn, Michigan: Society of Manufacturing Engineers.

Smith, J. S. and Tranfield, D. R. (1986) Managing Technological Change: Tackling Taken for Granted Assumptions. Proceedings of 3rd International Conference on Human Factors in Manufacturing, Stratford-upon-Avon. Kempston, UK: IFS Publications.

Stock dill, S. H. and Morehouse, D. L. (1991) Critical Factors in the Successful Adoption of Technology. TDC Research Report No. 15. St Paul: Minnesota, Telecommunications Development Center, University of Minnesota, Minnesota Extension Service.

Tranfield, D. and Smith, S. (1988) Managing rapid change. Management Decision, 26, I, 53-58.
US Congress. Office of Technology Assessment (1989) Linking for Learning: A New Course for Education. OTA-SET-430. US Government Printing Office, Washington, DC.

US Congress. Office of Technology Assessment (1990) Critical Connections: Communication for the future. OTA-CIT-407. US Government Printing Office, Washington, DC.

Wheeler, D. W. (1990) Organizational model. Paper prepared for the Institute of Agriculture and National Resources, University of Nebraska-Lincoln.

Wilhite, M. S., Leininger, A. and King, J. W. (1989) Managing faculty members in media units: research- based recommendations to enhance faculty growth. Educational Media International, 26,2, 111-114:

Zipkin, P. H. (1991) Does manufacturing need a JIT revolution? Harvard Business Review, 69, 1, 4050.

James W. King is Associate Professor and Instructional Designer, Communications and Computing Services Unit, University of Nebraska-Lincoln, USA.

Richard Cornell is Associate Professor, Instructional Systems, University of Central Florida, USA and the US ICEM representative.

Corresponding author - Dr James W. King, University of Nebraska-Lincoln, 104 ACB, Lincoln, NE 68583-0918, USA 